\title{
Multi-Door Courthouse established Through The European Mediation Directive?
}

\author{
Michal Malacka \\ Faculty of Law, Palacký University in Olomouc, Czech Republic \\ michal.malacka@upol.cz
}

MALACKA, Michal. Multi-Door Courthouse established through the European Mediation Directive? International and Comparative Law Review, 2016, vol. 16, no. 1, pp. 127-142. DOI: 10.1515/iclr-2016-0009.

\begin{abstract}
Summary: The article deals with the systematical problem of an acceptance and impementation of foreign law instruments in EU, incoming from Anglo-American law system. Supporting partial methods of the ADR, European legislative is focusing on the mediation and using this method in civil procedure law, especially in family law matters. The practitioners have accepted the idea of mediation as a part of civil law procedure without analyzing or studying the real nature of this method or instrument. The study is looking into the problematics of the Multi-Door Courthouse model and comparing it with European situation in the member states. It is also trying to find the best possible future ways for the development in the area of mediation with the reflection of the results of the implementation of the European mediation directive.
\end{abstract}

Keywords: Multi-Door Courthouse, European mediation directive, mediation, dispute resolution, appropriate dispute resolution, alternative dispute resolution, European Union member states, pre-steps to the court, benefits of arbitration, mediation pledge.

\section{The idea of the Multi-Door Courthouse}

The first person who has articulated the idea of Multi-Door Courthouse was an American professor of the Law School of the University of Harvard Frank Sander. ${ }^{1}$ His idea was formulated in the year of 1976 during a conference following the new ways in the administration of justice. ${ }^{2}$ During this conference an idea was introduced, covering the Courthouse as a Dispute Resolution Center offering a multiple choice of options or ways enabling fast resolution of legal disputes. Today we are discussing the nature of alternative dispute resolution, especially the nature of the real alternative to the dispute resolution by the state courts. The academic sphere and also the platform of practitioners in the field of arbitration are very often discussing the problem of the real alternative - of the only one alternative in the relation to arbitration and state court procedure.

1 KESSLER Gladys, FINKELSTEIN, Linda J. The Evolution of a Multi-Door Courthouse, Catholic University Law Review. 1988, vol. 37, no. 3, pp. 577-579.

2 KESSLER Gladys, FINKELSTEIN, Linda J. The Evolution of a Multi-Door Courthouse, Catholic University Law Review. 1988, vol. 37, no. 3, pp. 577-579. 
As the results of those discussions new shortcuts are established, actually new meanings of the old established shortcuts. ${ }^{3}$ So we can understand today the $\mathrm{ADR}$ as a way of appropriate dispute resolution or amicable dispute resolution. The most of European scientists in the field of alternative dispute resolution are concentrating their interests on the secondary questions. Analyzing only theoretical aspects without knowledge about the right way of using an instrument is not helping very much. If the European legislative has to come forward, the academic sphere should concentrate their interests on the functional understanding of the problem of the ADR as a part of a Multi-Door Courthouse system, as a part of a system transplanted to different low culture, in coming from AngloAmerican law to the continental system. ${ }^{4}$

From European perspective it is naturally a systematical problem of an acceptance of foreign instruments incoming from Anglo-American law system. Currently we are using partial methods of the ADR, European legislative is focusing on the mediation and using this method in civil procedure law, especially in family law matters. The practitioners have accepted the idea of mediation as a part of civil law procedure without analyzing or studying the real nature of this method or instrument. The right way, how to make the procedure at the state courts faster and easier is not only in the implementation of the mediation, we should concentrate on implementing the whole system of ADR. ${ }^{5}$

Coming back to the system of Frank Sanders, his idea was recognized as a functional instrument with a number of benefits for citizens in a part of the United States and its court systems. Some participants, judges and attorneys hoped that through this new system a new availability of alternative ways of resolving disputes could be built. ${ }^{6}$ Some of them presented the Multi-Door Courthouse system as a system which would present justice more accessible. More accessible especially by using all presented resolution techniques, with the possibility to design a new agreements, which could accelerating case processing and help the whole justice system. If we understand the Multi-Door Courthouse as the system of a reduction of the number of the bench and jury trials in the Anglo-American system, it could be also used in the European civil procedure systematic. Using not only mediation but also all the other amicable or appropriate dispute resolution after analyzing the nature of the dispute is transferring the old way of under-

3 Compare with Amicable Dispute Resolution: The Mediation Alternative and the Alberta Environmental Appeal Boardf, Ron Goltz in http://www.eab.gov.ab.ca/pub/Amicable\%20 Dispute\%20Resolution.pdf

4 LEIPNITZ, Desiree. Mediation im deutschen Arbeitsrecht und deren praktische Bedeutungunter besonderer erücksichtigung der US-amerikanischen Anwendung. Berlin: HWR Berlin, 2015, p.10; BIRNER, Marietta. Das Multi-Door Courthouse: ein Ansatz zur multi-dimensionalen Konfliktbehandlung, Köln: Otto Schmidt Verlag, 2003, pp. 205-208.

5 SCHWÄRZLER Helmut. Schiedsgerichtsverfahren und Mediation als Alternativen zur öffentlichen Gerichtsbarkeit, Liechtenstein-journal, 2011, vol. 3, no. 4, p. 115.

6 BIRNER, Marietta. Das Multi-Door Courthouse: ein Ansatz zur multi-dimensionalen Konfliktbehandlung, Köln: Otto Schmidt Verlag, 2003, p. 242. 
standing of the civil procedure into the new and may be fast and modern dispute resolution method.

\section{Mediation and arbitration as pre-steps to the court}

Before even thinking about implementation of the Multi-door Courthouse systematically, the mediation and arbitration shall be analyzed and introduced as pre-steps to the court proceedings. ${ }^{7}$ Mediation is appropriate dispute resolution method with a very rich history. Combined with the history of international private law and the historical aspects of international business we can find a lot of mediation methods also in the historical and political events.

Mediation is voluntary procedure, it should be confidential and aimed at dispute resolution and out of court way. Mediation involves a third-party as a person called the mediator. A person mediator as an independent third-party, that assists the parties to the dispute in reaching an acceptable settlement. In mediation the parties resolve the dispute on their own they are assisted by the mediator, so the mediation is based on parties' interests and not on the applicable law as a highest imperative. Mediation is much less formal, more flexible and much more controlled by the parties than the court or arbitration procedure. Why has the mediation been already used for a long time and what are the advantages of mediation? ${ }^{8}$

It was already mentioned that the mediation is a voluntary procedure, which is controlled by the parties. The parties are in the process of mediation directly engaged in the negotiations for dispute resolution, so that the parties have control over the dispute and its outcome. The aspect of voluntarism is presented in the mediation concerning the parties, which are not obliged even if they have agreed to refer the dispute to mediation, to continuing the mediation after the first meeting. So the parties always control if the mediation continues, or not. During the mediation resolution cannot be imposed on the parties. Parties, if they agreed with alternative dispute resolution, should also agree with the discovered possibility of a dispute resolution. Mediation, as an appropriate dispute resolution method, is fast. Most of the mediation cases are realized in a few days. ${ }^{9}$ If the mediation is fast it is also cheaper. ${ }^{10}$ Mediation is less expensive compared to litigation or arbitration procedure. Reducing expenses and the time

7 BIRNER, Marietta. Das Multi-Door Courthouse: ein Ansatz zur multi-dimensionalen Konfliktbehandlung, Köln: Otto Schmidt Verlag, 2003, p. 239-242.

8 GOLDBERG, Stephen B., SHAW, Margaret L. The Past, Present, and Future of Mediation as Seen through the Eyes of Some of Its Founders. Negotiation Journal, 2010, vol. 26, no. 2, pp. 237-253.

9 GOLDBERG, Stephen B., SHAW, Margaret L. The Past, Present, and Future of Mediation as Seen through the Eyes of Some of Its Founders. Negotiation Journal, 2010, vol. 26, no. 2, pp. 237-253.

10 Compare to study of LEATHES, Michael: 2020 Vision Where in the world will mediation be within 10 years? International Mediation Institute, 2010, https://imimediation.org/home 
for resolution safes funds of the parties. Mediation also helps parties overcome hostility in the relations and in some cases to establish grounds for a future relations base not only on layman's point of view and mutual interests but also on better understanding of the opposite party. The relationship between parties is secured also thanks to the confidential nature of the mediation. Mediation is confidential regarding all circumstances, documents and information's that become known to the participants in the mediation procedure. Mediation is not only confidential, it is also impartial. Impartial means that the parties are assisted by an impartial mediator. His role is to facilitate and actively assist the parties to communicate better and to seek and evaluate possible resolution of their dispute on their own. Very often mediators helped to explore options which exist, but have not been considered by the parties yet or ever. Mediation is also convenient; it is realized in a friendly and comfortable environment at the time convenient to the parties. Mediation is not only effective so that many cases result in agreement which is voluntarily executed by the parties it is also a win-win procedure. In the mediation both parties win because they reach a mutually acceptable agreement created by them..$^{11}$ This agreement corresponds to the needs and interests of the parties so it could be called a win-win agreement. Mediation also brings benefits to the court and to the civil procedure rules, it is reducing the workload of the court which gives the time to the court to focus on the more complicated cases. If it is combined with civil procedure rules it enables faster and favorable conclusion of court procedures. What is more important and very often forgotten is that mediation creates a new kind of culture in personal and business matters or communication if they are becoming a part of the dispute. ${ }^{12}$ Resolution of conflicts in the faster non-aggressive manner is establishing the bright field of conditions for successful interstate and international business activities and also protects legal and social stability. ${ }^{13}$

Mediation is a process of conflict management, where those who seek the assistance in a conflict, or accept an offer of help from an outsider, doesn't matter if it is an organization, group, state or individual. Mediation is practiced widely in international relations and as described above it is non-judgmental and it is particularly suited for the reality of international relations. Mediation is also used in political questions and in the international public law in so-called peacemaking. Mediation could have one very important role in the interstate relations, the importance of mediation and the international public law is however often forgotten. Mediation has a very important role in the context of intractable con-

11 GOLDBERG, Stephen B., SHAW, Margaret L. The Past, Present, and Future of Mediation as Seen through the Eyes of Some of Its Founders. Negotiation Journal, 2010, vol. 26, no. 2, pp. 237-253.

12 HOLÁ, Lenka a MALACKA Michal. Mediace a reflexe jejích aktuálních trendů. Praha: Leges, 2014, p. 33.

13 LEIPNITZ, Desiree. Mediation im deutschen Arbeitsrecht und deren praktische Bedeutungunter besonderer erücksichtigung der US-amerikanischen Anwendung. Berlin: HWR Berlin, 2015, pp. 17-20. 
flicts, where the parties in conflict lack direct channels of communication. There, were the states and other actors' guard the autonomy and independence, where the war conflict actually begun, there is a place for mediation. ${ }^{14}$

It is the free will of the parties that is the essential element of mediation. Only in a few jurisdictions party autonomy is limited since the court can compel parties to a legal dispute to engage in mediation. So the parties may use the autonomy to enter into binding consensual agreements to mediate. In most jurisdictions the settlement agreement between the parties can be concluded in a form which guarantees an enforceability of the resolution agreed upon. The strength of mediation lays in the very way it primary targets social conflicts, and in that the legal resolution has merely an auxiliary function.

Mediation is an appropriate dispute resolution mechanism. Distinguishing mediation from other forms of out-of-court conflict resolution brings some problems in the definition. As mentioned above ADR, so-called alternative dispute resolution represents a non-court system of dispute resolution. In most legal systems is or are the ADR presented as an alternative to the court. From analyzing the nature of arbitration mini trail, binding advice, the ombudsman procedure, conciliation, facilitation, and negotiation it becomes clear that there is only one real alternative to the court procedure. ${ }^{15}$ With the binding decision it is the arbitration which is the real alternative to the court procedure. As already mentioned the other methods, where one party is acting as a neutral element with different intensity level should be called appropriate dispute resolution methods. When distinguishing mediation from arbitration, the distinction is generally seen in the decision-making powers of the independent person. Before the state court it is the judge and in the arbitration the mediator arbitrator, who processes unilateral adjudicatory powers, while mediator does not. The difference is very important, but not as important as are the similarities. Various types of dispute resolution are systematically combined in the practice, so the parties sometimes combine mediation and arbitration in the form of med arb, so they can adjust the conflict resolution procedure to their needs. This is actually the point where we can start with the multidoor system implementation into the civil procedure rules. If the method of mediation and arbitration is and can be combined, there is no obstacle for establishing a system where the state court could or can decide what dispute has to be handled in mediation or in arbitration following his nature, before it goes to the court. In a lot of legal systems

14 FALK, Gerhard. Zur Geschichte der Mediation. In Manuskript zur Ausbildung der Österreichischen Rechtsanwälte, 2008, p. 3. Available at: http://docplayer.org/14793445-Zurgeschichte-der-mediation.html.

15 Concerning the the decision-making powers compare with VENZKE, Ingo. Die Schiedsgerichtsbarkeit löst die Rechtfertigungsprobleme internationaler Rechtsprechung nicht, Available at: http://voelkerrechtsblog.org/ and SCHWÄRZLER Helmut. Schiedsgerichtsverfahren und Mediation als Alternativen zur öffentlichen Gerichtsbarkeit, Liechtenstein-journal, 2011, vol. 3, no. 4, p. 112. 
the mediation, if it is not successful, switches to the court procedure. It is also used and known practice that the parties are switching the mediation to arbitration if the mediation is not successful and a binding decision is needed. What is the relationship between mediation and arbitration? Actually it is symbolical that the relationship between mediation and arbitration mirrors the relationship between mediation and the court proceedings. ${ }^{16}$ Mediation is and can be the first step of the structure of the dispute resolution and it has been already analyzed that if it is not successful it could be transformed to or followed by arbitration. In the relationship of mediation and arbitration the sequence can be agreed between the parties. In the relationship of mediation and court proceedings is the situation more difficult. Framework rules on mediation and arbitration often try to combine these two procedures to get the best of both methods. In some institutional arbitration courts the rule is that arbitration fee is reduced if the parties reach a settlement in mediation or if a pre- mediation was not successful. Some jurisdictions in Europe have integrated the mediation methods and techniques in the civil procedure rules. ${ }^{17}$ Even more some jurisdictions have established a mixed form of mediation and arbitration, so that they have developed the dispute resolution procedures not in the sense of a combination of both mechanisms but in using the basics of both methods. ${ }^{18}$ So it is possible for the intermediary to render a decision if the parties to the dispute failed to reach a settlement, the decision in this case will be binding only if the parties conclude a respective settlement agreement.

The benefits of mediation have been mentioned above. Also the benefits of arbitration are easy to mention because of lots of studies analyzing the profits for parties using arbitration as a dispute resolution method. Arbitration is preferred thanks to some significant advantages as party control, length of time, expense, flexible process, confidentiality, possibility of the selection of the arbitrator, finality, enforcement of international arbitration agreements and of awards ${ }^{19}$.

Arbitration is a created on contract, so the parties can by and thanks to the agreement designing the process, the parties autonomy of will is a very important aspect of the arbitration, not only in the relation to the nature and scope of discovery, or to the conduct of the hearing in the first place and the relationship of the applicable law, procedure rules and other basics of arbitration. According to statistics of international arbitration institutions the length of arbitration from

16 SCHWÄRZLER Helmut. Schiedsgerichtsverfahren und Mediation als Alternativen zur öffentlichen Gerichtsbarkeit, Liechtenstein-journal, 2011, vol. 3, no. 4, p. 112.

17 DAVIS, Laura. EU Foreign Policy, Transitional Justice and Mediation: Principle, Policy and Practice. New York: Routledge, 2014, pp. 28-33.

18 LEIPNITZ, Desiree. Mediation im deutschen Arbeitsrecht und deren praktische Bedeutung unter besonderer erücksichtigung der US-amerikanischen Anwendung. Berlin: HWR Berlin, 2015, pp. 31-35.

19 SCHLOSSER, Peter: Das Recht der internationalen privaten Schiedsgerichtsbarkeit. 2. Aufl.. Tübingen: Mohr Siebeck, 1989. 
the start to the final award was eight months on average..$^{20}$ Compared to the length of civil case following international statistics the arbitration is 40 times quicker than a civil procedure dispute resolution by a state court. As a benefit of the arbitration the expense is often mentioned. Arbitration attorney's fees and expenses are minimized because arbitration is generally concluded in a far less time than is the case in the court. So this benefit is combination of a flexible procedure and the length of time spent. The benefit of flexible process brings the possibilities for the parties to schedule hearings and deadlines to meet the objectives and their convenience. The flexibility of arbitration allows parties to save time and money by choosing the location of the hearing, taking of evidence such as testimony of witnesses, doing a conference with witnesses unable to attend, using written witness statements and so on. ${ }^{21}$

Very important benefit is the confidentiality of arbitration procedure. Arbitration hearings are held in private and are attended only by those designated by the parties and their counsel. This is a strong contrast to the proceedings held at the court because of their public nature. Confidentiality is an important aspect for many of corporations in the cases where their disputes involving intellectual property or trade secrets combined with concerns about publicity or damage to reputation. Second very important benefit of arbitration is the possibility to select the arbitrator. The parties can select the arbitrators with qualifications following the nature of the case. The qualification of an arbitrator includes number of years of experience, number of arbitration chaired, reputation of competence, also qualification and knowledge of foreign languages. ${ }^{22}$ Arbitration decision is prepared and resolved quickly and finally. Arbitration provides finality quickly and economically compared with state courts. In international commercial disputes so-called cross-border disputes is an arbitration agreement enforceable around the world thanks to the New York Convention ${ }^{23}$ signed by more than 140 states, in contrast judgments of national courts - not in European Union thanks to the harmonization and unification - but globally are more difficult and often impossible to enforce in other countries.

After the presentation of the benefits of mediation and arbitration let's return back to the Multi-door Courthouse model. The idea of Frank Sender is based on directing dispute in court to multiple dispute resolution doors providing the sense of options for the parties. This does not happen automatically, it is nec-

20 Controlling Time and Costs in Arbitration, ICC Publication 861-1 ENG, pp. 10-15. Available at: www.iccwbo.org.

21 Österreich, Internationales Schiedsgericht der Wirtschaftskammer: Handbuch Wiener Regeln: Ein Leitfaden für die Praxis. 1. Aufl.. : Service-GmbH der Wirtschaftskammer Österreich, pp. 256-282.

22 INGEN-HOUSZ, Arnold: ADR in Business: Practice and Issues Across Countries and Cultures. München: Kluwer Law International, 2011.

23 Convention on the Recognition and Enforcement of Foreign Arbitral Awards (New York, 1958) (the "New York Convention") 
essary to establish a system where the parties are referred to different dispute resolution options, after the consultation by the court they are able to select an option which is best suited to the needs of the particular dispute. In the model of Multi-door Courthouse are appropriate dispute resolutions and alternative dispute resolutions court annexed mediation, case evaluation, eerily neutral evaluation, arbitration and the continuation of litigation. ${ }^{24}$ In the United States where the project was established it resulting into programs of collaboration between judges, lawyers and volunteers willing to establish court annexed alternative dispute resolution.

The Anglo-American system serves with wider scale of opportunities and possibilities. So are for example in Georgia ${ }^{25}$ established Multi-door Courthouse dispute resolution centers where the citizens in dispute have input into the methods used to resolve the dispute. The goal of these centers is to offer alternative path to dispute settlement without experiencing the stress, expense and delay inherent in litigation. The centers offer mediation, case evaluation and arbitration. If one of the choices offered by the dispute resolution center is selected by the parties, a state registered and court approved mediator, evaluator or arbitrator will be appointed to assist the parties in resolving their dispute. By these procedures the appointed persons will remain neutral and for the future will not act as an advocate or attorney for either party. What is very important the costs of the center in respect to dispute resolution services are covered through the ADR trust found, at the reduce rate to parties. All conferences are confidential, the proceedings are less formal and significantly more relaxed than at the courtroom. Parties are given an opportunity to present their case in whatever method they welcome as the most appropriate. The services of Multi-door Courthouse center are reflecting the free will of the parties, all parties must agree to the dispute resolution process and after they agreed the center staff is available to assist in providing information in order for parties to make their decisions. ${ }^{26}$

Very important effect of this model is that the judges have increasingly become interested in Multi-door Courthouse program. It is clear that this new effort has proven its value and utility. Very important was also that the first step or first alternative program was conducted on small claims cases and thus the larger number of judges learned about mediation because of the rapid rotation

24 SANDER, Frank. A Dialogue between Professors Frank Sander and Mariana Hernandez Crespo: Exploring the Evolution of the Multi-Door Courthouse. University of St. Thomas Law Journal, 2008, vol. 5, no. 3, pp. 665-674. Available at: http://ir.stthomas.edu/ustlj/vol5/ iss $3 / 4$

25 EDWARDS, Barry. Renovating the Multi-Door Courthouse: Designing Trial Court Dispute Resolution Systems to Improve Results and Control Costs. Harvard Negotiation Law Review, 2013, vol. 18, no. Spring, pp. 284-294.

26 EDWARDS, Barry. Renovating the Multi-Door Courthouse: Designing Trial Court Dispute Resolution Systems to Improve Results and Control Costs. Harvard Negotiation Law Review, 2013, vol. 18, no. Spring, pp. 295-298. 
of judges in small claims assignment. The assistance of attorneys was also very important. Bar association's support was a strategic influence for this program because decisions in Multi-door Courthouse program have been made only with consulting attorneys. ${ }^{27}$ Attorneys also assisted in the development of guidelines to this program they also supported educational and public relations efforts. We can to now find a lot of articles and bar journals describing new model of Multi-Door Courthouse program. All the support was a strong help in search for mediators and arbitrators.

The role of mediation is very important in the Multi-door Courthouse model. Mediation is a technique that can for the future ensure appropriate and successful use in a broad variety of cases. Mediation can be used in small claims cases, also in a wide range of civil dispute involving hundreds, thousands or even millions in value. Even mediation can be however inappropriate in cases when the relationship between the parties has involved physical abuse. ${ }^{28}$ It is clear that mediators must be well trained for to refer all relevant information and facts, especially in cases involving property, and to protect the rights and interests of the parties as well as the children if the case involves family law matter.

The mediator selection has also very important role in the mediation and in the applied model. The most important factor in determining the success of the mediation procedure is and was the individual neutral involved. It is interesting to analyze the impact of the mediators on mediation outcomes. Some mediators are simply more effective than others. This fact is not based only on the quality of the mediator. It is clear that an average mediator can competently facilitate a simple mediation, but for a difficult case we need an exceptional mediator to settle complex, high conflict case. As a result average mediator may settle cases in a higher rate than exceptional mediator. The parties have the right to choose the mediator, they have to analyze the nature of the dispute and after analyzing, under the advisement of the attorney, choose the right mediator. ${ }^{29}$

Situation is better and not so complicated in Anglo-American sector thanks to a long tradition and thirty-year practice. In European Union some national legislation regulates mediation and her position in civil procedure law. The EU Directive and national law can set main borders for application of the mediation in the national legal system. ${ }^{30}$

27 EDWARDS, Barry. Renovating the Multi-Door Courthouse: Designing Trial Court Dispute Resolution Systems to Improve Results and Control Costs. Harvard Negotiation Law Review, 2013, vol. 18, no. Spring, p. 299.

28 VALENTOVA, Lucia. Mandatory mediation in family law issues with domestic violence limits and experience from USA. International and comparative law review, 2015, vol. 15, no. 2, pp. 101-120.

29 WERDT, Joseph Duss-von: Homo mediator: Geschichte und Menschenbild der Mediation. 1. Aufl. Stuttgart: Klett-Cotta, 2005, pp. 45-52.

30 Directive 2008/52/EC of the European Parliament and of the Council of 21 May 2008 on certain aspects of mediation in civil and commercial matters, OJ L 136, 24.5.2008, p. 3-8 


\section{Mediation in the European Union member states}

The EU Directive No 2008/52/EC is very important and can actually bring Multi-Door Courthouse in the European Union civil procedure. Even with less tradition than in Britain or in the United States ADR methods have been topic of discourse in many European nations since they have been successfully established in Anglo-American sector. Theoretical and practical discussions have been concentrated into the field of civil and commercial disputes. The European Union has noticed the importance of mediation combined with concern about court costs and overcrowding and with the necessary steps to put beside the obstacles in cross-border dispute resolution having influence on existence of the single market. The use of alternatives in civil procedure was voluntary, almost without corresponding legislative. In the year 1999 was the approach of ADR methods followed by a call for support of extra juridical dispute resolution process in the member states. The work on European Union mediation directive started 1999 and ended in 2008. ${ }^{31}$

Mediation directive expressly states that it applies only to cross-border disputes, but nothing should prevent member states from applying provision of the directive also to internal mediation process. The directive should secure a better access to justice. The idea was to secure access to exegetical dispute resolution methods. ${ }^{32}$ The directive should also ensure a balanced relationship between mediation and judicial proceedings. The last topic, balanced relationship between mediation and court procedure is an interesting idea, but it has to be understood as a wish for the future. Mediation directive had to be implemented in member states by May 2011. Many of member states did not wait until the deadline to implement the directive. In a number of states the mediation directive had already been included in domestic law for a number of years. Especially in those states where the ADR has had a long tradition. ${ }^{33}$

In the 2012 European Parliament returned to the focus on mediation process, the legal affairs committee resumed the need to promote appropriate settlement of disputes through mediation. European Parliament declined to answer the question if the mediation directive's objective had been attained with the argumentation of a short time after the implementation. It was already mentioned that in some countries mediation has had a good tradition but in some countries arise the new paradox, so-called European Union paradox, where the existence

311999 European Council of Tampere foreshadowed a significant effort to change its 'laissezfaire' approach, when it called for the creation of alternative extrajudicial dispute resolution procedures by the Member States

32 https://www.mediationaktuell.de/news/adr-richtlinie-und-odr-verordnung-eu-im-ueberblick

33 LEUTHEUSSER-SCHNARRENBERGER Sabine. Die Mediations-Richtlinie und deren Implementierung. Zeitschrift für Konfliktmanagement, 2012, vol. 15, no. 3, pp. 72-74. 
of an effective process was established but only a very few people use it or are able to use it. ${ }^{34}$

Why is the situation so complicated? Are we really talking about paradox way of mediation existence? The situation in European Union is not so bad; also in United States was the approach toward mediation a long time way with slow efforts. But we cannot compare the situation in United States with the situation in the Continental system without mentioning its specifications. The basic problem is the relationship between mediation, promoters of mediation which are mediators, courts and of course policymakers, governmental and nongovernmental organizations who are playing also important role and users of mediation, the parties to the disputes. The group mentioned above, promoters of mediation, somehow failed to convince the users, parties to pay full attention to mediation and take full advantage of its potential. Governments and policymakers have presented all benefits of mediation such as cost-saving, time effectiveness, confidentiality and use of friendly procedure arguments by preparing mediation law and establishing it. And here we are. When establishing national mediation legislature and implementation of the mediation directive, there are some weak points to be noticed. If we concentrate in each member state not only on the answer if the mediation was implemented but also how and with what result we have to also analyze implementation policies, mediation marketing, mediator's behavior and practice and structure of the mediation laws. ${ }^{35}$

Analyzing the reasons and ideas combined with mediation procedure and establishing it in the system of civil procedure, the argument always mentioned was the overcrowding of the courts and expensive proceedings. ADR methods were also a part of counterculture, people wanted noncompetitive, less costly, and more time effective and less damaging way of solving the disputes. ${ }^{36}$

Interesting is that the people were not aware of that. Directive has shown that people do not necessarily shun confrontation and competition especially in those cases when they believe they were right and they have to fight. Even mediation, which is in the nature voluntary and supported by politicians the idea of mandatory mediation was born may be because the studies have shown that the satisfaction with mediation is not consistently greater compared to satisfaction with courts. Naturally most of the supporters of mandatory mediation are the mediators themselves, supported by a lot of academics and organizations. There are only a few studies remembering the real nature of mediation, appropriate or amicable dispute resolution method used only after free choice of parties and fol-

34 See to this aspects http://www.europarl.europa.eu/sides/getDoc.do?type=OQ\&reference=O2012-000169\&language $=\mathrm{EN}$.

35 Czech mediation act report - http://mediator-praha.cz/docs/zakon-o-mediaci-duvodovazprava.pdf, p. 1.

36 http://kluwermediationblog.com/EU Mediation Directive 
lowing their free will. ${ }^{37}$ If one understands mediation as a method using negotiation and communication and on the other hand we force the people to negotiate, we will see no light in the end of the mediation tunnel. All mentioned interests of mediation advocates, policymakers and professional mediators forcing people into using a service they do not like or found useful are not compatible with the fundaments of $\mathrm{ADR} \cdot{ }^{38}$

Promoting mediation as a way to ease the load of court was a mistake people actually do not care about. The reason to use mediation should be actually based on comfort and prospect of amicable way of handling disputes, not the systematical mistake or overwhelmed judges juggling the case load. Who will convince the parties to use mediation or go through the mediation open-minded only using the argument, that they have to be good citizens and pay for resolution of the own dispute in order to safe public funds? The promotion of mandatory mediation is a very dangerous in the aspect of the right to unrestrained access to justice ${ }^{39}$ Mediation, in her traditional and historical nature is a cost effective way of dispute resolution, but only if we compare it with the civil procedure and judicial way of dispute resolution, not combined! Mediation needs collaboration in the marketing, may be in the same way like Multi-door Courthouse, but not by ordering something what is and has been a misunderstanding. Also the position of mediators in Europe does not help a lot. Not only the mediators are not able to understand day activity and practice of mediation in the same way, also the governments of European Union member states understand the nature and position of the mediator in the different ways. ${ }^{40}$

Implementations of the EU directive in national law systems are really different. The European Union has not only problems of agreeing on a common definition of what constitutes mediation and what does not. The position of the mediator and his rights and duties are in the comparative view established in some countries very well, and in some in very complicated form. In the article 3 of the EU directive is a mediation described as a structured process, however named or referred to, whereby two or more parties to the dispute attempt by themselves, on a voluntary basis, to reach an agreement on the settlement of their dispute with the assistance of a mediator. This process may be initiated by the parties or suggested or ordered by a court or prescribed by the law of a

37 De PALO, Giuseppe; TREVOR, Mary B. EU Mediation Law and Practice. New York, London: OUP, 2012; ESPLUGUES MOTA, Carlos; MARQUIS, Louis. New Developments in Civil and Commercial Mediation: Global Comparative Perspectives. Berlin, Heidelberg: Springer, 2015, $762 \mathrm{p}$.

38 BARRETT, Joseph: A History of Alternative Dispute Resolution: The Story of a Political, Social, and Cultural Movement, New York: John Wiley \& Sons, 2004., pp. 209-239.

$39 \mathrm{http} / /$ www.mediate.com/articles/poundconference.cfm

40 Question for oral answer to the Commission Rule 115 by Klaus-Heiner Lehne, on behalf of the Committee on Legal Affairs O-000169/2012, see also http://www.mediate.com/articles/PaloResponse.cfm 
member state. In this definition are the member states of the European Union following reasonable and effective definition of mediation. But the definition of the mediator was in some countries misunderstood and written in the law intentionally in the limited form or method. ${ }^{41}$

So for example the German law ${ }^{42}$ is describing mediator as an independent and neutral person without decision competencies, which is leading the parties through the mediation. Austrian law is describing the mediator in the same paragraph as the mediation. The mediation is a procedure based on free will of the parties realized by a highly qualified, neutral intermediary, mediator who is using accepted methods of communication between the parties and is systematically leaving them to the resolution found out by the parties. The mediation law of the Czech Republic ${ }^{43}$ leads completely wrong and is describing mediator as a person belonging to the list of mediators. Mediator is not a natural person subscribed to the list of mediators! It is clear, that this "List-regulation" is a bad legislative construction, because all mediators using mediation as a non-subscribed in the list of Ministry of justice are actually acting against the law. It seems that they cannot use the mediation methods when not registered formally in the list of the Ministry of Justice. The same way, no so wrong way actually, was the definition of mediator established in the Slovak Act on Mediation. ${ }^{44}$ As mediator can act every natural person registered in the registry of mediators, but for to act as a mediator, the person has to accept the function of mediator! This is again an administrative obstacle, destroying the potential of mediation in the wide scale of methods and the disputes.

In Belgium is mediation governed by the federal law. ${ }^{45}$ Mediation procedures are governed by Rules of Civil Procedure what is very important because federal law prevents regional legislation to cause any differences in regions. What is interesting is that mediation is codified in the general Code of Civil Procedure, what is a very good instrument. The most important fact in this codification is that mediation is supposed to be a type of civil and commercial dispute resolu-

41 Compare with BATTELLI Ettore et al. (Eds.). Pan-european mediation practices. Eurochambres, 2014, p. 15-33. Available at: http://www.eurochambres.eu/custom/Volume Pan_European_practises_in_EU-2014-00891-01.pdf.

42 https://www.gesetze-im-internet.de/bundesrecht/mediationsg/gesamt.pdf, Mediationsgesetz vom 21. Juli 2012 (BGBl. I S. 1577), das durch Artikel 135 der Verordnung vom 31. August 2015 (BGBl. I S. 1474) geändert worden ist.

43 Mediation act Nr.202/2012 Sb., zákon o mediaci, in the $\$ 2$ of the mediation act is the combination of lit a) and lit c) very interesting. The definition of mediation at lit.a) and at lit. c) the definition of mediator construct a definition of mediation - procedure, where only registered subject can act.

44 Mediation act Nr. 420/2004 Z. z.Zákon o mediácii a o doplnení niektorých zákonov, Slovak construction is better, but also not ideal. As mediator can act each natural person, but also registered....

45 http://www.gotomediation.eu/legal-information/countries/belgium/Code judiciaire/Gerechtelijk Wetboek 
tion. Mediation could be applied at any stage in the proceedings except in proceedings before the Belgian Supreme Court. What is also important is that parties can enter into mediation during the judicial dispute and also before or after the court proceedings. The legislation of mediation had already been enacted in Belgium before the EU directive of mediation was passed. In Belgium the parties may present a demand for referral by submitting a letter to the clerk of the court even before the court proceedings. The parties may present after the commencement of proceedings the mediation demand and the judge will appoint an accredited mediator. In Belgium a federal commission for accreditation has been created. ${ }^{46}$ The commission has the power to accredit mediators according to criteria for the type of mediation. Belgian legislation is working with the term accredited mediator. For a mediator to became an accredited mediator the candidate must illustrate professional experience for the practice of mediation, must provide guarantees of independence and impartiality, the candidate must not have been condemned for a crime and the subject to disciplinary or administrative sanctions incompatible with the function of mediator. Mediators must also absolve education. The education is divided into 40 hours of basic training and 60 hours of specialization training. Very important for the system is that mediation is an instrument in all corresponding civil law matters.

The same situation as in Belgium according to legislation is in Denmark. There is no special Act governing mediation. Mediation is included into the Justice $\mathrm{Act}^{47}$ and covers mediation realized through the court system. Even if Denmark is not bound by the directive following the opt-out, the legislation of mediation conforms to the provisions of the EU directive. Interested are the requirements for mediators. Mediators have to have a relevant education with legal background, and that means that judges and lawyers can be appointed as mediators. There is an education census applied.

Following the nature of mediation is legislation of Estonia ${ }^{48}$, establishing the conditions and requirements for mediators following the nature of amicable dispute method. There are no requirements for registration or license to be a mediator. Mediator can be an attorney, notary or natural person. Natural persons acting as mediators do not need special accreditation. What is important in this context is legislation. In Estonian legislation there are no court annexed mediation's procedures mentioned.

Ireland is going further with no registration or accreditation for mediators. Compact with the real nature of ADR, any person may act as a mediator. With-

$46 \mathrm{http} / / /$ www.cepani.be/en/mediation/belgian-legislation, see also https://e-justice.europa.eu/content_mediation_in_member_states-64-be-en.do?member=1

47 ERVO Laura; NYLUND Anna. The Future of Civil Litigation: Access to Courts and Courtannexed Mediation in the Nordic Countries, Heidelberg: Springer, 2014, pp. 157-185.

48 NURMELA Ilona; PÕLDVERE Pirkka-Marja. Efficiency of Mediation in Commercial Disputes with Emphasis on Estonia. 2014. Available at http://apilv.ee/static/SAR_2-2014_EfficienyofMediation.pdf 
out being registered, trained or certified and what is more important the position or better the role of mediator is not protected or prohibited by law. Ireland does not have and this is the same situation like an Estonia, court annexed mediation procedures. ${ }^{49}$

The definition of mediation is not the same in the national legislation. It is very complicated to introduce something, to introduce some method, if it is not defined. A lot of mediators are forgetting that they have to serve the parties and they have to choose methods used by mediation according to the nature of the dispute, not according to theoretical school or mediators' preferences. But a lot of mediators are also calling for more rules, common statute of the mediation, for more official structures representing them and for more registrations and evaluations, all against nature of mediation. It seems like all involved subjects have forgotten the same. The most important are the parties; we can also say users of the mediation, all policymakers or legislators and all mediators involved in the mediation establishment procedure should start with the most important, with the parties.

\section{Resume}

Establishing Multi-door Courthouse method in European Union is a longterm process, that is just at the beginning. We can find in some studies terms like Mediation Pledge. ${ }^{50}$ Inspired by the ADR pledge in the United States, Mediation Pledge in UK and Singapore, introducing mediation as an important instrument for the business dispute resolution are motivating EU to try to reach the same standard. However in the EU we have to be careful not to get the mediation plague instead of the Mediation Pledge. It would be maybe useful to think back about the long way what was needed in the case of arbitration and its use. The differentiation between appropriate dispute resolution and alternative dispute resolution should not destroy the alternative as an option. Mediation is an important instrument but cannot be used in the wrong way. If we remember arbitration definition, as an alternative dispute resolution method chosen freely by parties, where is the ADR spirit in the case of mediation and its placement in European procedure law forgotten? Or is mediation saved by opt-out system? So the party can continue with state court procedure after the first meeting with the mediator which was not successful? If we wish in the European Union massive approach of mediation we have to answer the questions above with yes. For to establish mediation as a real instrument, is the mandatory mediation necessary, but we cannot forget its true nature and for the future it would be better to direct the national legislatives in order to bring them to constructive and traditional

$49 \mathrm{http} / / /$ mediateireland.com/mediation-law-ireland

50 See also http://www.mediatehawaii.org/mediation-pledge/, http://www.gotomediation.eu/ fileadmin/docs/eurochambres_mediation-manifesto_2014-12-10.pdf, http://kluwermediationblog.com/2013/03/09/new-adr-pledge/ 
ICLR, 2016, Vol. 16, No. 1.

concepts of mediation. If not, we will only have another kind of civil procedure established without the Multi-door Courthouse possibilities. 